\begin{tabular}{|l|l|l||}
\hline \multicolumn{2}{|c|}{ PublisherInfo } \\
\hline \hline PublisherName & $:$ & BioMed Central \\
\hline \hline PublisherLocation & $:$ & London \\
\hline \hline PublisherImprintName & $:$ & BioMed Central \\
\hline \hline
\end{tabular}

\title{
Lasker Awards presented for work on ubiquitination and hepatitis $\mathrm{C}$
}

\begin{tabular}{|c|c|c|}
\hline \multicolumn{3}{|c|}{ ArticleInfo } \\
\hline ArticleID & : & 3772 \\
\hline ArticleDOI & : & 10.1186/gb-spotlight-20000921-02 \\
\hline ArticleCitationID & : & spotlight-20000921-02 \\
\hline ArticleSequenceNumber & : & 209 \\
\hline ArticleCategory & : & Research news \\
\hline ArticleFirstPage & : & 1 \\
\hline ArticleLastPage & : & 4 \\
\hline & & RegistrationDate : $2000-09-21$ \\
\hline & & : 2000-09-21 \\
\hline ArticleCopyright & : & BioMed Central Ltd2000 \\
\hline ArticleGrants & & \\
\hline
\end{tabular}


William Wells

Email:wells@biotext.com

SAN FRANCISCO, September 18. Since 1962, more than half of those honored with the Lasker Basic Medical Research Award, often called "America's Nobels", have gone on to receive the Nobel Prize. The whisperings about a cell-cycle Nobel were only heightened by the 1998 Basic Medical Lasker, which was shared by Lee Hartwell, Paul Nurse and Yoshio Masui for their discovery of a conserved cell cycle engine. Now the 2000 Basic Medical Lasker has been bestowed on three researchers for their work on ubiquitination, a process that controls protein destruction. Perhaps the most famous targets of the ubiquitination system are various cyclins that control progression through the cell cycle.

The recipients of the 2000 Basic Medical Lasker are Aaron Ciechanover and Avram Hershko (both at Technion-Israel Institute of Technology, Haifa, Israel) and Alexander Varshavsky (California Institute of Technology, Pasadena, California). The 2000 Lasker Award for Clinical Medical Research goes to Harvey Alter (National Institutes of Health, Bethesda, Maryland) and Michael Houghton (Chiron Corporation, Emeryville, California) for work leading to the discovery of the hepatitis $\mathrm{C}$ virus and effective screening methods that eliminated the virus from blood transfusion supplies. Sydney Brenner (Molecular Sciences Institute, Inc., Berkeley, California) receives the 2000 Lasker Award for Special Achievement in Medical Science for work on the genetic code, introduction of the worm Caenorhabditis elegans as a model organism, and contributions to the debates and methodologies of the genomics era.

With the award to Ciechanover, Hershko and Varshavsky, an unfashionable area gets its due. Hershko started investigating protein degradation in the late 1960s, when the emphasis in cell and molecular biology was on the myriad controls that the cell exerts over the creation of proteins. Protein destruction was seen as dull in comparison: a constitutive, largely unregulated process. But protein stabilities vary widely, and Hershko found that the destruction of some proteins required the energy of ATP.

Immature red blood cells were the perfect laboratory for Hershko's investigation of protein destruction. Joined in 1977 by Ciechanover, he broke open the cells and started fractionating.

One of the fractions needed to reconstitute destruction activity retained activity after boiling. Ciechanover and Hershko purified the factor, APF-1, which would later be shown to be identical to a small, previously isolated protein of unknown function called ubiquitin.

The researchers used radioactively labeled ubiquitin to show that multiple copies of ubiquitin were covalently bonded to other proteins prior to the proteins' destruction. They also determined that three enzymes (E1, E2 and E3) were required to execute this linkage.

Ciechanover and Hershko had focussed on cell extracts, so it was left to Varshavsky to establish the importance of the ubiquitin system in living cells. Varshavsky and Ciechanover (then both at the Massachusetts Institute of Technology, Cambridge, Massachusetts) showed that mutant mouse cells that could divide at $32^{\circ} \mathrm{C}$ but not at $39^{\circ} \mathrm{C}$ had a defective $\mathrm{E} 1$ enzyme, and had lost the ability to destroy short-lived or abnormal proteins. 
As the list of proteins targeted by ubiquitin grew, biologists realized that control of protein destruction was as vital as control of protein synthesis. Ubiquitin controls the abundance of cyclins, other cell cycle proteins, p53 (when bound to a human papilloma virus protein), and immune system proteins. Signals on these target proteins are recognized by a family of E3 enzymes; the first of these signals was elucidated by Varshavsky in 1986.

The work of Alter and Houghton made transfusion a less risky proposition. In 1970 the risk of contracting hepatitis from a transfusion was close to $30 \%$. Alter spearheaded an effort to reduce this risk by tracking blood from donor to recipient. Most of the tainted blood, he found, was coming from paid donors, and was often associated with hepatitis B virus infection. By switching to an all-volunteer blood donation system, and instituting hepatitis B testing of donated blood, hepatitis rates were reduced to $10 \%$.

By now hepatitis A virus had also been characterized. But a 'non-A, non-B hepatitis' (NANBH) problem remained. Alter injected blood from NANBH patients into chimpanzees and showed that the animals came down with hepatitis. Fractionation of the blood showed that this transmissible agent was a virus surrounded by a lipid envelope. Alter also raised the profile of NANBH by showing that, despite the mild liver inflammation symptoms, $20 \%$ of infected patients developed cirrhosis.

Conventional searches for virus proteins and antibodies to those proteins were proving fruitless in tracking down the causative agent of NANBH. Houghton took a new approach: he extracted DNA and RNA from infected chimpanzees, put the pieces into bacteria so they could drive the production of proteins, and then looked for bacteria producing proteins that bound antibodies from infected, but not uninfected, people. An exhaustive search led to hepatitis $\mathrm{C}$ virus, and a blood test that has reduced transfusion-related infection rates to almost zero.

Sydney Brenner won the 1971 Albert Lasker Basic Medical Research Awardfor establishing basic tenets of molecular biology: the existence of messenger RNA (mRNA), the triplet theory and related concepts of translation, and the language of stop codons.

But in the mid-1960s he moved on. "We thought that most of the important problems had been solved", he says. His next target was developmental biology. He searched for an ideal model organism and came up with the roundworm $C$. elegans. The worm's fixed number of cells, developing in a stereotyped pattern, allowed Brenner and his students to tackle subjects such as cell signaling and apoptosis, and to define an entire wiring diagram for the worm's nervous system. Brenner provided inspiration for the worm genome project, which was completed in 1998.

Meanwhile, Brenner had switched fields again. By the 1990s he was embracing genomics in all its forms. Most recently he has pursued these interests as founder and president of the Molecular Sciences Institute and scientific guru at Lynx Therapeutics, Inc. (Hayward, California), a company using microbeads to do genome-wide scans. Although he has for some years been 'retired', Sydney Brenner is far from idle. 


\section{References}

1. Albert \& Mary Lasker Foundation Living Library: Lee Hartwell, [http://www.laskerfoundation.org/ library/hartwell/index.html]

2. Albert \& Mary Lasker Foundation Living Library: Paul Nurse, [http://www.laskerfoundation.org/ library/nurse/index.html]

3. Albert \& Mary Lasker Foundation Living Library: Yoshio Masui, [http://www.laskerfoundation.org/ library/masui/index.html]

4. Previous Lasker Award Winners - Basic Research Awards, [http://www.laskerfoundation.org/library/ prev1.html]

5. The Albert \& Mary Lasker Foundation, [http://www.laskerfoundation.org] 